\title{
Races of Phytophthora sojae and Their Virulences on Soybean Cultivars in Heilongjiang, China
}

\author{
Shuzhen Zhang and Pengfei Xu, Soybean Research Institute, Northeast Agricultural University, Harbin 150030, \\ China; Junjiang Wu, Soybean Research Institute, Heilongjiang Academy of Agricultural Sciences, Harbin 150086, \\ China; Allen G. Xue and Jinxiu Zhang, Eastern Cereal and Oilseed Research Centre, Agriculture and Agri-Food Can- \\ ada (AAFC), Ottawa, Ontario K 1A 0C 6, Canada; Wenbin Li and Chen Chen, Key Laboratory of Soybean Biology of \\ Chinese Education Ministry, Northeast Agricultural University, Harbin 150030, China; Weiyuan Chen, Suihua Re- \\ search Institute, Heilongjiang Academy of Agricultural Sciences (HAAS), Suihua 152052, China; Eastern Cereal and \\ Oilseed Research Centre, Agriculture and Agri-Food Canada (AAFC), Ottawa, Ontario K 1A 0C 6, Canada; and \\ Huiying Lv, Institute of Genetics and Developmental Biology, Chinese Academy of Sciences, Beijing 100101, China
}

\begin{abstract}
Zhang, S. Z., Xu, P. F., Wu, J. J., Xue, A. G., Zhang, J. X., Li, W. B., Chen, C., Chen, W. Y., and Lv, H. Y. 2010. Races of Phytophthora sojae and their virulences on soybean cultivars in Heilongjiang, China. Plant Dis. 94:87-91.

Phytophthora root and stem rot, caused by Phytophthora sojae, is an economically important disease of soybean (Glycine max) in Heilongjiang Province, China. The objectives of this research were to determine the race profile of $P$. sojae in Heilongjiang and evaluate soybean cultivars for reactions to the pathogen races. A total of 96 single-zoospore $P$. sojae isolates were obtained from soil samples collected from 35 soybean fields in 18 counties in Heilongjiang from 2005 to 2007. Eight races of $P$. sojae, including races 1, 3, 4, 5, 9, 13, 44, and 54, were identified on a set of eight differentials, each containing a single resistance Rps gene, from 80 of the 96 isolates. Races 1 and 3 were predominant races, comprising 58 and 14 isolates, and representing 60 and $7 \%$ of the pathogen population, respectively. Races $4,5,44$, and 54 were identified for the first time in Heilongjiang, and each was represented by two to three isolates only. Sixty-two soybean cultivars commonly grown in Heilongjiang Province were evaluated for their resistance to the eight $P$. sojae races identified using the hypocotyl inoculation technique. Based on the percentage of plant mortality rated 5 days after inoculation, 44 cultivars were resistant $(<30 \%$ mortality) to at least one race. These cultivars may be used as sources of resistance in soybean breeding programs.
\end{abstract}

Phytophthora root and stem rot, caused by Phytophthora sojae Kaufmann \& Gerdemann, is a destructive disease of soybean (Glycine $\max (\mathrm{L}$.$) Merr.) worldwide$ $(8,31)$. The disease was first observed in Indiana in 1948 and Ohio in 1951 in the United States, and the causal agent was described in 1955 (14). Phytophthora root and stem rot reduces soybean yield by 10 to $40 \%$ (2), and severe infection can result in a total yield loss. China is the third largest soybean producing country in the world, following the United States and Brazil. P. sojae was not found in China until 1991, when Shen and Su (28) isolated the pathogen for the first time in Heilongjiang Province where most of the soybean are grown in China. Since then, the disease has become widespread in Heilongjiang, and the annual infected

Corresponding author: A. G. Xue

E-mail: allen.xue@agr.gc.ca

Accepted for publication 17 September 2009.

doi:10.1094/PDIS-94-1-0087

(C) 2010 Department of Agriculture and AgriFood, Government of Canada area is estimated at over 150,000 ha $(11,20,32)$.

The pathogenic variation of $P$. sojae was first reported in 1955 (14). To date, there have been at least 55 races identified based on their reactions on a set of 8 or 13 differentials, each containing a single resistance gene $(10,13,17,23)$. Although new races of $P$. sojae may appear with the release of resistant cultivars, the use of genetic resistance still remains the most effective strategy to reduce losses caused by the pathogen (6). A total of 14 single dominant genes (Rps) at eight genomic loci conferring resistance to specific races of $P$. sojae, including Rps $1 \mathrm{a}, R p s 1 \mathrm{~b}, R p s 1 \mathrm{c}, R p s 1 \mathrm{~d}$, Rps 1k, Rps2, Rps3a, Rps3b, Rps3c, Rps4, Rps5, Rps6, Rps7, and Rps8, have been reported in the world $(1,3,16)$.

Monitoring the racial composition and dynamics of the pathogen population is a key component of resistance breeding programs to Phytophthora root and stem rot. Race 1 was the first $P$. sojae race identified in Heilongjiang in 1999 (22). Since then, races $3,9,11,13,17,21$, and 24 have also been reported $(20,21,33,36)$. These races were identified from the pathogen collected in isolated fields in a few coun- ties in Heilongjiang. There has been no extensive research on race profile and dynamics of the pathogen population in Heilongjiang, resulting in a lack of information needed by the regional resistance breeding programs. The objectives of this research were to collect and characterize $P$. sojae isolates from soybean fields across Heilongjiang Province, and to evaluate soybean cultivars commonly grown in the province for their resistance to the various races.

\section{MATERIALS AND METHODS}

Field sampling. Soil samples were collected from 10 fields in 7 counties in 2005 , 16 fields in 12 counties in 2006, and 9 fields in 7 counties in 2007 . The 18 counties where the 35 samples were collected are shown in Figure 1. Fields were selected for sampling based on the presence of Phytophthora root and stem rot symptoms. In each field, a bulk sample of approximately $2 \mathrm{~kg}$ of soil was collected from at least five random sites, and soil was taken to a depth of $15 \mathrm{~cm}$ from the rhizosphere of severely affected plants using a hand trowel. The soil samples were air-dried and stored at $3^{\circ} \mathrm{C}$ before being used for pathogen isolation.

Isolation of $\boldsymbol{P}$. sojae. The re-activation of $P$. sojae in the soil samples was conducted using the baiting method described by Canaday and Schmitthenner (4) and the isolation of the fungus using the soybean seedling bioassay procedure described by Schmitthenner and Bhat (26). Each soil sample was ground to fine particles and placed in vinyl pots (10 $\mathrm{cm}$ diameter). The potted soil was flooded for $24 \mathrm{~h}$ and then allowed to dry slowly in the dark at room temperature until the soil began to pull away from the sides of the pots. To induce oospore germination, pots were placed in plastic bags for approximately 2 weeks until planting. Ten seeds of soybean cultivar Williams (rpsrps), susceptible to all known $P$. sojae races, were placed on the surface of the potted soil and covered with wet coarse vermiculite. Pots were then placed in clear plastic bags in the growth chamber operated at $25^{\circ} \mathrm{C}$ day and $20^{\circ} \mathrm{C}$ 
night with a 16-h photoperiod at a light intensity of $335 \mu \mathrm{mol} \cdot \mathrm{m}^{-2} \cdot \mathrm{s}^{-1}$. Three days after planting, when primary roots were about $5 \mathrm{~cm}$ long, the pots were removed from the bags, flooded again for $24 \mathrm{~h}$, and returned to the growth chamber. Affected plants showing prominent lesions or collapse of hypocotyls were identified and used for pathogen isolation within 10 days after planting.

To isolate the pathogen, sections $(1 \mathrm{~cm})$ cut from the margin of lesions on hypocotyls were surface-disinfested in $0.25 \%$ sodium hypochlorite solution for $3 \mathrm{~min}$, and in $70 \%$ ethanol for $10 \mathrm{~s}$, then washed in sterilized distilled water, dried with a sterile paper towel, and placed on the semiselective PBNIC medium (26), containing Terrachlor ( $99 \%$ pentachloronitrobenzene) at $0.04 \mathrm{~g} /$ liter, Benlate ( $50 \%$ benomyl) at $0.01 \mathrm{~g} / \mathrm{liter}$, neomycin sulfate at 0.10 $\mathrm{g} /$ liter, Rovral (50\% iprodione) at 0.04 $\mathrm{g} / \mathrm{liter}$, and chloramphenicol at $0.10 \mathrm{~g} / \mathrm{liter}$ in a V8 juice agar base. Hyphae tips of $P$. sojae that grew out of the infected tissues were cut 3 days after plating and transferred to the PBNIC medium for further purification and identification. $P$. sojae was identified by microscopic examination using taxonomic keys and illustrated morphological manuals for Phytophthora spp. $(7,24,30)$.

Single-zoospore isolates. At least one single-zoospore isolate of $P$. sojae was developed from each soil sample following the procedure of Jackson et al. (13). Fifteen $6-\mathrm{mm}$ agar plugs from the edge of a culture actively growing on V8 juice agar were transferred to Erlenmeyer flasks con- taining $25 \mathrm{ml}$ of $\mathrm{V} 8$ juice broth for $48 \mathrm{~h}$. The V8 juice broth was decanted and the plugs were washed with $25 \mathrm{ml}$ of Chen and Zentmyer's (5) salt solution at $\mathrm{pH} 7.0$ four times at 15 -min intervals. The plugs were then incubated in $20 \mathrm{ml}$ of sterile distilled water under cool-white $40 \mathrm{~W}$ lights at room temperature for $48 \mathrm{~h}$ until zoospores were observed using a stereomicroscope. Zoospore concentrations were estimated using hemacytometer. Through serial dilutions, the concentration of the zoospore suspension was adjusted to approximately $1 \times 10^{3}$ spores $/ \mathrm{ml}$ and plated onto quarterstrength V8 juice agar medium (agar 5.0 g/liter). Single-zoospore isolates were obtained by transferring a single, germinating zoospore to V8 juice agar. A total of 96 single-zoospore isolates were obtained from the 35 soil samples collected in 18 counties during 2005, 2006, and 2007. Each of those single-spore isolates came from a separate isolate, which came from a separate seedling. Single-zoospore cultures were maintained on V8 juice agar slants, incubated at room temperature for 10 days, covered with $2 \mathrm{ml}$ of sterile deionized water, stored at $15^{\circ} \mathrm{C}$, and subcultured if needed every 3 months before virulence characterization tests.

Virulence characterization. A set of eight differentials, each containing a single resistance Rps gene, and the universal suscept Williams (rps) were used to test each of the 96 single-zoospore isolates of $P$. sojae. The eight differentials included L75-3735 (Rps1c), L75-6141 (Rps1a), L77-1863 (Rps1b), L83-570 (Rps3a), L891581 (Rps6), L93-3258 (Rps7), P.I.103

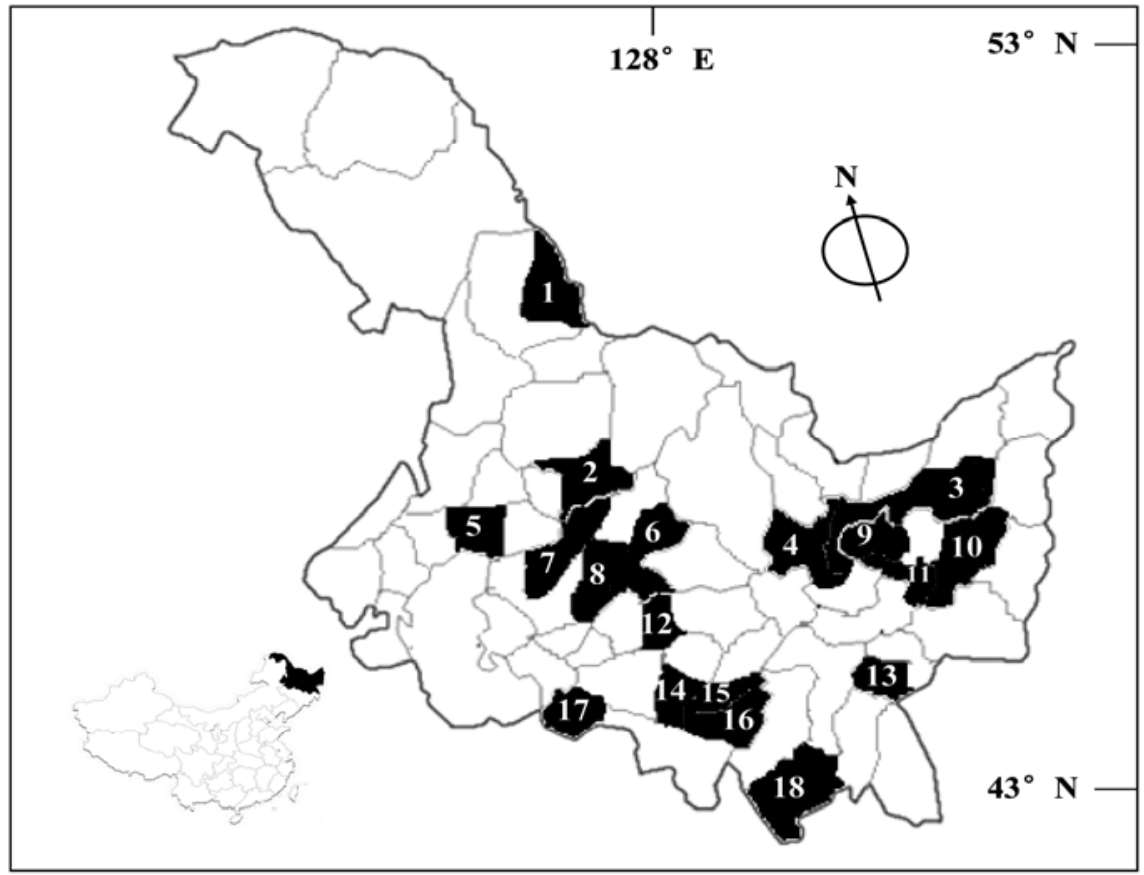

Fig. 1. Map of Heilongiang Province, China showing 18 counties where Phytophthora sojae isolates were collected. 1 = Heihe, 2 = Bei'an, $3=$ Jiansanjiang, $4=$ Jiamusi, $5=$ Yi'an, $6=$ Qing' an, $7=$ Hailun, $8=$ Suihua, $9=$ Jixian, $10=$ Baoqing, $11=$ Shuangyashan, $12=$ Bayan, $13=$ Jixi, $14=$ A'cheng, 15 = Yanshou, 16 = Shangzhi, 17 = Shuangcheng, 18 = Ning' an .
(Rps1d), and Williams 82 (Rps1k) $(13,27)$. The seed of the differential set was obtained from T. R. Anderson at Harrow Research Center, Agriculture and Agrifood Canada in 2003 and increased in a glasshouse of the Key Laboratory of Soybean Biology, Chinese Education Ministry in Harbin, Heilongjiang in 2004.

For the virulence characterization tests, the differentials were grown in $12-\mathrm{cm}$ diameter plastic pots containing a sterilized soil:peat:perlite mixture $(1: 1: 1)$ with five plants per pot in growth chambers at $25^{\circ} \mathrm{C}$ day and $20^{\circ} \mathrm{C}$ night temperature with a 16-h photoperiod at a light intensity of $335 \mu \mathrm{mol} \cdot \mathrm{m}^{-2} \cdot \mathrm{s}^{-1}$. Plants were watered twice weekly from the bottom of the pot. The potting mixture contained sufficient nutrients to support healthy plant growth during the course of the experiments.

Inoculum was prepared by growing each single-zoospore isolate of $P$. sojae on V8 juice agar in a $9-\mathrm{cm}$ petri dish at $25^{\circ} \mathrm{C}$ for 7 days. Plants were inoculated using a hypocotyl wound inoculation technique described by Kaufmann and Gerdemann (14) at the first-node stage (V1) (9), which occurred 7 to 9 days after planting. Seedlings were slightly incised with a blade along the hypocotyls, and a weft $(10 \times 10$ $\mathrm{mm}$ ) of aerial mycelium obtained from the margin of a 7-day-old $P$. sojae culture on V8 juice agar was inserted into the longitudinal wound. After inoculation, the inoculated plants were placed in a mist chamber with $100 \%$ relative humidity at $24^{\circ} \mathrm{C}$ with $12 \mathrm{~h}$ light for 3 days, and then returned to the growth chambers.

The differential reaction to each isolate was determined with five plants per pot and four replicate pots for each differential in each experiment. The replicate pots of each differential within an experiment were arranged in a complete randomized design, and the experiment was conducted three times for each isolate and differential interaction. In each experiment, four pots of cultivar Williams (rps) that were wounded and inoculated with sterile V8 juice agar were included as checks, indicating possible damage of wounding to plants.

The percentage of dead plants was recorded 5 days after inoculation. If a differential exhibited $<30 \%$ seedling mortality, the reaction was considered resistant. If a differential exhibited $>70 \%$ seedling mortality, the reaction was considered susceptible. Seedling mortality from 30 to $70 \%$ was considered an intermediate reaction $(1,13,34)$. Isolates that produced either resistant or susceptible responses to individual differential cultivars that were consistent in three repeated experiments were characterized to race. Isolates that produced intermediate reactions to at least one of the eight differentials in at least three consecutive attempts were considered unclassifiable $(13,17)$.

Resistance screening. Sixty-two shortseason soybean cultivars (Maturity Groups 
I to 000) commonly grown in Heilongjiang Province were evaluated for reactions to the eight $P$. sojae races identified in this study in a greenhouse in 2008. Plants were grown and inoculated using the same methods described above. One isolate from each of the eight races was used for inoculating the plants. The reaction of soybean cultivars to each race was determined with five plants per pot and four replicate pots for each cultivar in each experiment. The pots were arranged in a complete randomized design, and the experiment was conducted twice.

\section{RESULTS}

Race identification and distribution. Of the $22 P$. sojae isolates obtained in 2005, 19 were classified into 6 races, and 3 had intermediate reactions (Table 1 ). In 2006, 31 of the 44 isolates were classified into 6 races, and 13 had intermediate reactions. In 2007, all 30 isolates obtained were classified into 6 races. A total of 8 races of $P$. sojae were identified during the 3 years. Of the $8 P$. sojae races identified, race 1 predominated, comprising $60 \%$ of the isolates, followed by race 3 which made up $7 \%$ of the isolates. Races 4, 5, 9, 13, 44, and 54 were detected infrequently, each comprised of two to three isolates, representing 2 to $3 \%$ of the population. Races 4, 5, 44, and 54 have not been previously reported in Heilongjiang Province. The 16 unclassifiable isolates were grouped into 14 intermediate reaction types (IRT) based on their virulence formulae and assigned IRT1 to IRT14 (Table 1).

Race 1 was found in all 18 counties, while races 5,44 , and 54 were each found in a single county (Table 2). There were four to seven $P$. sojae races and IRT identified in each of Jixi, Jiamusi, Jiansanjiang, and Jixian counties where more severe disease development was observed at the time of sample collection. These four counties were located in the eastern part of the province in Sanjiang Plain, where the typical soil type is low-lying and poorly drained clay soil. The remaining counties each had only one to three races identified.

Cultivar resistance. The percentage of mortality of the 62 soybean cultivars to each of the eight $P$. sojae races ranged from 0 to $100 \%$ in both experiments. Based on percentage of plant mortality averaged over the two experiments, 44 cultivars were resistant ( $<30 \%$ mortality) to at least one of the eight races, and the remaining were susceptible (Table 3). Of the resistant cultivars, Hefeng-50 was resistant to five races; Hefeng-45 and Xingkangxian-1 were resistant to four races; Hefeng-42, Hefeng-44, Heihe-32, Heinong-46, Heinong-47, Suinong-8, Suinong-11, and Suinong-19 were resistant to three races; and Dongnong-44, Dongnong49, Heihe-16, Heinong-40, Nen-14, Suinong-2, Suinong-21, Suinong-23, and
Xingdou-4 were resistant to two races. Intermediate reactions (30 to $70 \%$ mortality) were observed in a number of cultivar and race combinations, but none of the 62 cultivars showed an intermediate response to all eight races.

\section{DISCUSSION}

This study demonstrates that race 1 is the predominant race of $P$. sojae in Heilongjiang Province. The result is in agreement with earlier reports from China $(18,20,33,36)$. However, four races, including races $11,17,21$, and 24 , reported earlier in Heilongjiang Province were not found in this study. Likewise, four races, including races $4,5,44$, and 54, identified in the present study have not been previously reported. The virulence formulae of the eight races identified were closely related. For example, race 1 ( $r p s 7)$, race 3 (rps1a, rps7), race 13 (rps6, rps7), and race 54 (rps $1 \mathrm{~d}, r p s 7)$ share the same pattern of virulence, differing by only one gene among those races. Similarly, race 4 (rpsla, rps $1 \mathrm{c}$, rps7) differs from race 5 (rps $1 \mathrm{a}$, rps 1c, rps6, rps7), race 9 (rps1a, rps6, rps7), and race 44 (rps1a, rps1d, rps7) by only one gene. The results support the remark of several Phytophthora researchers that the virulence formulae of races within the same region were similar, usually differ-

Table 1. Eight races and 14 intermediate reaction types (IRT) of Phytophthora sojae identified from 96 isolates collected in Heilongiiang Province, China in 2005, 2006, and 2007

\begin{tabular}{|c|c|c|c|c|c|}
\hline \multirow[b]{2}{*}{ Race and IRT } & \multirow[b]{2}{*}{ Virulence formula $(r p s)^{\mathrm{z}}$} & \multicolumn{4}{|c|}{ Number of isolates } \\
\hline & & 2005 & 2006 & 2007 & Total \\
\hline 1 & 7 & 12 & 22 & 24 & 58 \\
\hline 3 & $1 \mathrm{a}, 7$ & 2 & 4 & 1 & 7 \\
\hline 4 & $1 \mathrm{a}, 1 \mathrm{c}, 7$ & 0 & 1 & 1 & 2 \\
\hline 5 & $1 \mathrm{a}, 1 \mathrm{c}, 6,7$ & 1 & 1 & 1 & 3 \\
\hline 9 & $1 \mathrm{a}, 6,7$ & 1 & 0 & 1 & 2 \\
\hline 13 & 6,7 & 1 & 0 & 2 & 3 \\
\hline 44 & $1 \mathrm{a}, 1 \mathrm{~d}, 7$ & 2 & 1 & 0 & 3 \\
\hline 54 & $1 \mathrm{~d}, 7$ & 0 & 2 & 0 & 2 \\
\hline IRT1 & $\pm 1 \mathrm{a}, 1 \mathrm{~b}, 6,7$ & 0 & 1 & 0 & 1 \\
\hline IRT2 & $\pm 1 \mathrm{a}, 1 \mathrm{c}, 1 \mathrm{~d}, 1 \mathrm{k}, 7$ & 0 & 1 & 0 & 1 \\
\hline IRT3 & $1 \mathrm{a}, \pm 1 \mathrm{~d}, 7$ & 1 & 0 & 0 & 1 \\
\hline IRT4 & $1 \mathrm{a}, 1 \mathrm{c}, \pm 3 \mathrm{a}, 7$ & 1 & 0 & 0 & 1 \\
\hline IRT5 & $1 \mathrm{~b}, \pm 3 \mathrm{a}, 7$ & 0 & 2 & 0 & 2 \\
\hline IRT6 & $1 \mathrm{c}, 1 \mathrm{k}, \pm 3 \mathrm{a}, 7$ & 0 & 2 & 0 & 2 \\
\hline IRT7 & $1 \mathrm{k}, \pm 3 \mathrm{a}$ & 0 & 1 & 0 & 1 \\
\hline IRT8 & $\pm 3 a, 7$ & 0 & 1 & 0 & 1 \\
\hline IRT9 & $\pm 3 a, 6,7$ & 1 & 0 & 0 & 1 \\
\hline IRT10 & $3 \mathrm{a}, \pm 7$ & 0 & 1 & 0 & 1 \\
\hline IRT11 & $\pm 1 \mathrm{a}, 1 \mathrm{~b}, \pm 1 \mathrm{c}, 1 \mathrm{~d}, 1 \mathrm{k}, 3 \mathrm{a}, 7$ & 0 & 1 & 0 & 1 \\
\hline IRT12 & $\pm 1 \mathrm{~b}, 1 \mathrm{c}, \pm 3 \mathrm{a}$ & 0 & 1 & 0 & 1 \\
\hline IRT13 & $1 \mathrm{a}, \pm 1 \mathrm{~b}, 1 \mathrm{c}, 1 \mathrm{~d}, 1 \mathrm{k}, \pm 3 \mathrm{a}$ & 0 & 1 & 0 & 1 \\
\hline IRT14 & $\pm 1 \mathrm{c}, 1 \mathrm{~d}, 6, \pm 7$ & 0 & 1 & 0 & 1 \\
\hline Total & & 22 & 44 & 30 & 96 \\
\hline
\end{tabular}

${ }^{\mathrm{z}} \pm=$ intermediate reaction (30 to $70 \%$ mortality).

Table 2. Distribution of eight races and 14 intermediate reaction types (IRT) of Phytophthora sojae in 18 counties of Heilongjiang Province during 2005 to 2007

\begin{tabular}{lccl}
\hline Origin & No. of samples & No. of isolates & Race and IRT ${ }^{\mathbf{z}}$ \\
\hline Heihe & 1 & 3 & Race 1(1), Race9(1), IRT4(1) \\
Bei'an & 1 & 5 & Race 1(4), IRT3(1) \\
Jiansanjiang & 5 & 16 & Race 1(7), Race 13(3), Race 3(3), Race 5(3) \\
Jiamusi & 4 & 8 & Race 1(3), Race 44(3), IRT8(1), IRT2(1) \\
Yi'an & 2 & 4 & Race 1(1), Race 3(3) \\
Qing'an & 2 & 2 & Race 1(1), Race 9(1) \\
Hailun & 5 & 9 & Race 1(8), IRT9(1) \\
Suihua & 1 & 2 & Race 1(2) \\
Jixian & 3 & 13 & Race 1(9), Race 54(2), IRT14(1), IRT13(1) \\
Baoqing & 1 & 1 & Race 1(1) \\
Shuangyashan & 1 & 6 & Race 1(4), IRT5(1), IRT10(1) \\
Bayan & 1 & 1 & Race 1(1) \\
Jixi & 2 & 15 & Race 1(8), Race 3(1), Race 4(1), IRT6(2), \\
& & & IRT12(1), IRT1(1), IRT7(1) \\
A'cheng & 1 & 1 & Race 1(1) \\
Yanshou & 2 & 5 & Race 1(3), IRT5(1), IRT11(1) \\
Shangzhi & 1 & 3 & Race 1(2), Race 4(1) \\
Shuangcheng & 1 & 1 & Race 1(1) \\
Ning'an & 1 & 1 & Race 1(1) \\
Total & 35 & 96 & \\
\hline
\end{tabular}

${ }^{\mathrm{z}}$ Values in the brackets are numbers of isolates. 
ing from one another by virulence on only one Rps gene $(1,13,15,27,34)$.

None of the eight races were virulent on Rpslb, Rpslk, and Rps3a genes (Table 1). However, 11 of the 14 IRT were virulent on at least one of the three resistance genes, and IRT13, represented by a single isolate, was virulent on all three resistance genes. In addition, none of the eight $P$. sojae races $(1,3,9,11,13,17,21$, and 24$)$ reported in Heilongjiang in the previous studies was virulent on Rps1c gene, but two of the four new races identified in the present study, races 4 and 5 , were able to overcome the Rps1c resistance. These results raise concerns on the diversity and dynamics of the $P$. sojae population in Heilongjiang and the likelihood of continued occurrence of new races and IRT possessing virulence on Rps 1c and Rps 1k, which are commonly used Rps genes in the soybean breeding program $(13,19,25)$.

This study further demonstrates that resistance to all $P$. sojae races is available in soybean cultivars commonly grown in Heilongijiang Province. Previous efforts in screening soybean germplasm in Heilongjiang for resistance to $P$. sojae had focused on resistance to race 1 or up to two races $(20,35,36)$. This is to our knowledge the first report on the identification of sources of resistance to all eight races for Heilongjiang. Twenty of the 44 resistant cultivars identified in the present study were resistant to more than one race of $P$. sojae (Table 3 ), and the use of these cultivars in a breeding program will enable the pyramiding of genes in subsequent generations to develop multiple gene resistance for broader effectiveness against the pathogen.

Thirty-three of the 44 cultivars were susceptible to $P$. sojae race 1 but resistant to at least one of the seven remaining races identified (Table 3). These results were unexpected, as race 1 possesses only one virulence gene (rps7) and is the least virulent race. If a cultivar is susceptible to race 1 , it should have a susceptible interaction with all of the other races. A possible explanation was that there might be additional virulences in the race 1 isolate used that were not found in the other isolates where there is a resistant reaction. There might also be a possibility that the U.S. differentials do not work for the isolates from Heilongjiang Province.

$P$. sojae is known for its pathogenic variability $(8,25)$. New races of $P$. sojae can shorten the effective lifespan of a resistant cultivar and may also have virulence against resistance genes that are not currently present in soybean cultivars, rendering these genes ineffective even before the genes are used in a breeding program. However, the use of genetic resistance remains the most effective method of managing Phytophthora root and stem rot. In recent years, a number of plant pathologists and breeders have expressed preference for the use of race-non-specific or partial resistance, described as the ability of plants to survive the pathogen infec-

Table 3. List of 44 soybean cultivars with resistance to at least one of the eight races of Phytophthora sojae identified in Heilongjiang, China

\begin{tabular}{|c|c|c|c|c|c|c|c|c|}
\hline \multirow[b]{2}{*}{ Cultivar } & \multicolumn{8}{|c|}{ Plant mortality $(\%)^{\mathrm{z}}$} \\
\hline & Race 1 & Race 3 & Race 4 & Race 5 & Race 9 & Race 13 & Race 44 & Race 54 \\
\hline Suinong-9 & 21 & 90 & 73 & 100 & 56 & 100 & 100 & 100 \\
\hline Heihe-20 & 100 & 50 & 100 & 100 & 55 & 50 & 100 & 0 \\
\hline Suinong-18 & 100 & 100 & 75 & 55 & 39 & 90 & 100 & 15 \\
\hline Dongnong-42 & 100 & 54 & 100 & 91 & 90 & 100 & 94 & 0 \\
\hline Heinong-38 & 90 & 95 & 85 & 87 & 91 & 95 & 94 & 0 \\
\hline Heinong-49 & 100 & 92 & 100 & 100 & 100 & 78 & 100 & 0 \\
\hline Heihe-9 & 100 & 100 & 61 & 45 & 58 & 95 & 25 & 50 \\
\hline Suinong-4 & 100 & 100 & 55 & 100 & 91 & 95 & 25 & 61 \\
\hline Dongnong-47 & 100 & 88 & 95 & 95 & 75 & 100 & 14 & 45 \\
\hline Hefeng-47 & 92 & 94 & 14 & 81 & 54 & 100 & 100 & 83 \\
\hline Hefeng-35 & 100 & 92 & 18 & 55 & 61 & 100 & 74 & 82 \\
\hline Heihe- 6 & 100 & 100 & 28 & 95 & 63 & 100 & 97 & 100 \\
\hline Heinong-37 & 95 & 95 & 15 & 100 & 79 & 95 & 62 & 100 \\
\hline Hefeng-41 & 73 & 61 & 100 & 0 & 73 & 73 & 42 & 91 \\
\hline Heihe-5 & 55 & 100 & 100 & 23 & 95 & 59 & 100 & 63 \\
\hline Heihe-19 & 100 & 90 & 89 & 24 & 95 & 100 & 90 & 55 \\
\hline Suinong-16 & 85 & 85 & 55 & 0 & 79 & 95 & 100 & 55 \\
\hline Suinong-15 & 100 & 85 & 100 & 5 & 62 & 45 & 94 & 75 \\
\hline Dongnong-40 & 82 & 0 & 79 & 58 & 56 & 79 & 100 & 95 \\
\hline Hefeng-43 & 100 & 95 & 90 & 100 & 75 & 11 & 47 & 55 \\
\hline Heihe-27 & 100 & 85 & 89 & 84 & 78 & 15 & 100 & 55 \\
\hline Suinong-20 & 55 & 50 & 95 & 100 & 77 & 0 & 57 & 57 \\
\hline Suinong-12 & 60 & 55 & 100 & 100 & 50 & 5 & 50 & 55 \\
\hline Suinong-7 & 57 & 62 & 80 & 100 & 79 & 8 & 90 & 90 \\
\hline Heihe-16 & 85 & 95 & 1 & 100 & 95 & 100 & 100 & 0 \\
\hline Suinong-2 & 25 & 10 & 100 & 100 & 58 & 100 & 85 & 90 \\
\hline Suinong-23 & 45 & 99 & 75 & 100 & 78 & 100 & 22 & 10 \\
\hline Suinong-21 & 10 & 95 & 100 & 0 & 61 & 63 & 53 & 55 \\
\hline Dongnong-49 & 56 & 95 & 5 & 100 & 100 & 0 & 95 & 100 \\
\hline Dongnong-44 & 100 & 100 & 23 & 0 & 86 & 61 & 100 & 51 \\
\hline Xingdou-4 & 56 & 100 & 47 & 11 & 90 & 56 & 78 & 21 \\
\hline Heinong-40 & 100 & 95 & 57 & 27 & 55 & 95 & 95 & 0 \\
\hline Nen-14 & 46 & 95 & 100 & 0 & 24 & 56 & 100 & 100 \\
\hline Hefeng-44 & 0 & 62 & 100 & 83 & 23 & 55 & 45 & 4 \\
\hline Hefeng-42 & 5 & 100 & 100 & 97 & 60 & 100 & 23 & 1 \\
\hline Suinong-11 & 23 & 95 & 85 & 100 & 100 & 100 & 5 & 0 \\
\hline Heihe-32 & 0 & 45 & 24 & 60 & 62 & 45 & 100 & 1 \\
\hline Heinong-46 & 28 & 76 & 20 & 100 & 100 & 45 & 100 & 0 \\
\hline Suinong-8 & 15 & 75 & 80 & 95 & 90 & 15 & 95 & 23 \\
\hline Suinong-19 & 45 & 100 & 15 & 20 & 100 & 15 & 100 & 58 \\
\hline Heinong-47 & 13 & 0 & 90 & 85 & 100 & 55 & 100 & 0 \\
\hline Hefeng-45 & 92 & 64 & 12 & 1 & 92 & 21 & 97 & 4 \\
\hline Xingkangxian-1 & 90 & 100 & 0 & 0 & 85 & 10 & 100 & 7 \\
\hline Hefeng-50 & 21 & 20 & 54 & 12 & 91 & 100 & 24 & 22 \\
\hline
\end{tabular}

z Values are the average of two experiments, 20 plants in four replicate pots of each experiment. 
tion without displaying severe disease symptoms or yield loss $(3,6,29)$. Breeding for partial resistance to Phytophthora root and stem rot in Heilongjiang is still in the developmental stage (12). Given the fact that new and more virulent races and IRT have been frequently identified during the past several years, cultivars with high levels of partial resistance would be more desirable as sources of resistance for soybean breeding programs dealing with the P. sojae population in Heilongjiang.

\section{ACKNOWLEDGMENTS}

This research was supported by Program for New Century Excellent Talents from Universities in Heilongiiang Province (NCET-06-007), NSFC project $(30671317,30810103063,30400285)$, NSF in Heilongjiang (C200814), and Postdoctoral Foundation of China (20060400835).

\section{LITERATURE CITED}

1. Anderson, T. R., and Buzzell, R. I. 1992. Diversity and frequency of races of Phytophthora megasperma f. sp. glycinea in soybean fields in Essex County, Ontario, 19801989. Plant Dis. 76:587-589.

2. Anderson, T. R., and Tenuta, A. 2003. Phytophthora Rot. Pages 155-156 in: Diseases of Field Crops in Canada. K. L. Bailey, B. D. Gossen, R. K. Gugel, and R. A. A. Morrall, eds. Canadian Phytopathological Society. University Extension Press, University of Saskatchewan, Saskatoon, Canada.

3. Burnham, K. D., Dorrance, A. E., VanToai, T. T., and St. Martin, S. K. 2003. Quantitative trait loci for partial resistance to Phytophthora sojae in soybean. Crop Sci. 43:1610-1617.

4. Canaday, C. H., and Schmitthenner, A. F. 1982. Isolating Phytophthora megasperma f. sp. glycinea from soil with a baiting method that minimizes Pythium contamination. Soil Biol. Biochem. 14:67-68.

5. Chen, D. W., and Zentmyer, G. A. 1970. Production of sporangia of Phytophthora cinnamomi in axenic culture. Mycologia 62:397402.

6. Dorrance, A. E., McClure, S. A., and St. Martin, S. K. 2003. Effect of partial resistance on Phytophthora stem rot incidence and yield of soybean in Ohio. Plant Dis. 87:308-312.

7. Erwin, D. C., Bartnick-Garcia, S., and Tsao, P. H. 1983. Phytophthora: Its Biology, Taxonomy, Ecology, and Pathology. American Phytopathological Society, St. Paul, MN.

8. Erwin, D. C., and Ribeiro, O. K. 1996. Phytophthora Diseases Worldwide. American Phy- topathological Society, St. Paul, MN.

9. Fehr, W. R., Caviness, C. E., Burmood, D. T., and Pennington, J. 1971. Stage of development descriptions for soybeans, Glycine $\max (\mathrm{L}$.) Merrill. Crop Sci. 11:929-931.

10. Grau, C. R., Dorrance, A. E., Bond, J., and Russin, J. S. 2004. Fungal Diseases. Pages 679-763 in: Soybeans: Improvement, Production, and Uses. H. R. Boerma and J. E. Specht, eds. 3rd ed. ASA, CSSA, and SSSA Publishers, Madison, WI.

11. Han, X. Z., He, Z. H., and Zhang, Z. M. 1998. The prevention technique of main disease and pests of soybean. Soybean Bull. 6:5-6.

12. Han, Y., Teng, W., Yu, K., Anderson, T. R., Poysa, V., Qiu, L., and Lightfoot, D. 2008. Mapping QTL tolerance to Phytophthora root rot in soybean using microsatellite and RAPD/SCAR derived markers. Euphytica 162:231-239.

13. Jackson, T. A., Kirkpatrick, T. L., and Rupe, J. C. 2004. Races of Phytophthora sojae in Arkansas soybean fields and their effects on commonly grown soybean cultivars. Plant Dis. 88:345-351.

14. Kaufmann, M. J., and Gerdemann, J. W. 1958. Root and stem rot of soybean caused by Phytophthora sojae. Phytopathology 48:201-208.

15. Kenney, B. W. 1984. Root rot of soybean in Minnesota: The changing race situation in Phytophthora megasperma f. sp. glycinea. Plant Dis. 68:826.

16. Kilen, T. C., Hartwig, E. E., and Keeling, B. L. 1974. Inheritance of a second major gene for resistance to Phytophthora root rot in soybeans. Crop Sci. 14:260-262.

17. Leitz, R. A., Hartman, G. L., Pedersen, W. L., and Nickell, C. D. 2000. Races of Phytophthora sojae on soybean in Illinois. Plant Dis. 84:487.

18. Li, C. S., Lu, X. B., Liu, T. J., Lin, I. L., Qi, J. S., and $\mathrm{Xu}, \mathrm{Z}$. T. 2001. Identification of race of Phytopthora sojae and screening of soybean cultivar resistance. Chinese J. Oil Crop Sci. 23:60-63.

19. Lohnes, D. G., Nickell, C. D., and Schmitthenner, A. F. 1996. Origin of soybean alleles for Phytophthora resistance in China. Crop Sci. 36:1689-1692.

20. Lv, H. Y., Kong, F. J., Xu, X. H., Yuan, X. L., and Yang, Q. K. 2001. Response of soybean germplasm from the Northeast China to Phytophthora root rot caused by Phytophthora sojae. Chinese J. Oil Crop Sci. 23:16-18.

21. Ma, S. M., Ding, J. J., Zheng, T. Q., and Gu, X. 2005. The identification of physiological races of Phytophthora megasperma. Soybean Sci. 24:260-262.

22. Ma, S. M., and Li, B. Y. 1999. A preliminary report on the identification of the physiological races of Phytophthora megasperma. Soybean Sci. 18:151-153.

23. Morgan, F. L., and Hartwig, E. E. 1965. Physiologic specialization in Phytophthora megasperma var. sojae. Phytopathology 55:12771279.

24. Newhook, F. J., Waterhouse, G. M., and Stamps, D. J. 1978. Tabular key to the species of Phytophthora. Mycol. Pap. Commonw. Mycol. Inst., Kew, Surrey, England.

25. Schmitthenner, A. F. 1989. Phytophthora rot. Pages 35-38 in: Compendium of Soybean Diseases. J. B. Sinclair and P. A. Backman, eds. American Phytopathological Society, St. Paul, $\mathrm{MN}$.

26. Schmitthenner, A. F., and Bhat, R. G. 1994. Useful methods for studying Phytophthora in the laboratory. OARDC Special Circ. 143 Ohio State University, Wooster.

27. Schmitthenner, A. F., Hobe, M., and Bhat, R. G. 1994. Phytophthora sojae races in Ohio over a 10-year interval. Plant Dis. 78:269276.

28. Shen, C. Y., and Su, Y. C. 1991. Discovery and preliminary studies of Phytophthora megasperma on soybean in China. Acta Phytopathol. Sinica 21:198.

29. Tooley, P. W., and Grau, C. R. 1984. Field characterization of rate-reducing resistance to Phytophthora megasperma f. sp. glycinea in soybean. Phytopathology 74:1201-1208.

30. Waterhouse, G. M. 1963. Key to the species of Phytophthora de Bary. Mycol. Pap. 92:1-22.

31. Wrather, J. A., Anderson, T. R., Arsyad, D. M. Gai, J., Ploper, L. D., Porta-Puglia, A., Ram, H. H., and Yorinori, J. T. 1997. Soybean disease loss estimates for the top 10 soybean producing countries in 1994. Plant Dis. 81:107110.

32. Xu, X. H., Lv, H. Y., Qu, J. J., and Yang, Q. K. 2002. Isolation method for Phytophthora sojae and investigation for the infected regions. Soybean Sci. 21:147-150

33. Xu, X. H., Lv, H. Y., Qu, J. J., and Yang, Q. K. 2003. Phytophthora sojae races in Northeast of China and the virulence evaluation of the isolates. Acta Phytopathol. Sinica 30:125-128.

34. Yang, X. B., Ruff, R. L., Meng, X. Q., and Workneh, F. 1996. Races of Phytophthora sojae in Iowa soybean fields. Plant Dis. 80:14181420.

35. Zhang, S. Z., Xu, P. F., Wu, J. J., and Li, W. B. 2007. Identification of resistance to Phytophthora sojae in soybean germplasm. Soybean Sci. 26:914-917.

36. Zhu, Z. D., Wang, X. M., Chang, R. Z., Ma, S M., Wu, X. F., and Tian, Y. L. 2000. Identification of race of Phytophthora sojae and reaction of soybean germplasm resources in Heilongjiang province. Sci. Agric. Sinica 33:62-67. 